\title{
Content Factor to Promote Islamic Weblog Continuance Uses
}

\author{
MOHD SAZILI SHAHIBI, MUHAMMAD NORMAN MASREK \& \\ NURUL HAFIZ IBRAHIM ${ }^{1}$
}

\begin{abstract}
Religious information is now being disseminated through various internet applications including weblogs. Providing digital Islamic Information content online via the internet is vulnerable. Its exposure to the modification of information was taken from the original information resources by irresponsible parties. This research paper is about examining the information content and relationship of each factor that encourages the peoples to continue to use the Islamic weblogs and able to recognize between the true and false on Islamic information teaching. Quantitative research method was applied for data collection and about 800 questionnaires have been distributed to Islamic religious subject teachers. Finding of the study revealed significant value for content factors such as Continuance Use, Satisfaction, Perceived Usefulness that promote continued use of Islamic web blog. Hypotheses analysis of the finding indicated only content factors like Reliability and Confirmation, Perceived Usefulness and Satisfaction, Confirmation and Satisfaction, Continuance Use and Satisfaction have supported each other for prediction continuances use of Islamic web blog
\end{abstract}

Keywords: Information Management, Islamic Digital Information, Content Management, Library Science, Islamic Information System.

Development of Internet technology has improved tremendously the growth of digital religions information resources. The Dakwah (missionary work) approach has been influenced by the technology and being used for the needs. Religious information is now being disseminated through various internet applications including weblogs. In response to this scenario, it is essential to ensure that any Ulama or Islamic scholar works especially regarding the Al-Quran and Al-hadith translation are being discussed based on original and trustworthy sources of information. Al-Quran is the main source and reference to Muslim Society. The Al-Quran could not be edited or new arrangement because Allah has informed that Al-Quran will preserve from any alteration forever until the The Day of Judgment. "We have, without doubt, sent down the message: and we will assuredly guard it (from corruption)" (15:9). Providing digital Islamic Information content online via the internet is vulnerable. It is exposed to the modification of information by irresponsible parties. Due to the situation, objective of this research paper is about examining the information content and relationship of each factors that encouraging the people to continue uses the Islamic weblogs as the core medium in browsing and searching for the information regarding the fundamentals and practices of Islam. By continuance use of Islamic web blogs, the Internet users can recognise or distinguish between the true and false on Islamic information teaching.

${ }^{1}$ Mohd Sazili Shahibi, Ph.D., Professor at Faculty of Information Management, Universiti Teknologi Mara, Puncak Perdana Campus, Jln Pulau Angsa AU10/A, 40150 SHAH ALAM, Malaysia. Email: mohdsazili@salam.uitm.edu.my; Muhammad Norman Masrek, Ph.D., Professor at Faculty of Inforation Management, Universiti Teknologi Mara, Puncak Perdana Campus, Jln Pulau Angsa AU10/A, 40150 SHAH ALAM, Malaysia. Email: mnoorman@uitm.edu.my; Mohd Nurul Hafiz Ibrahim, Ph.D., is an Information System Consultant in Kuala Lumpur, Malaysia. Email: hafizibrahim313@gmail.com

$$
\text { https://doi.org/10.24035/ijit.19.2021.196 }
$$




\section{Islam and Internet}

Blog is well recognized as a medium for the main source of online information among Internet among to Internet users. Content of the blog is accessible regardless of the boundaries regardless boundaries of time and places. Blog has become one of the most common applications in spreading information on the internet. Blog has been acknowledged has acknowledged as one of the most influential digital media that is able that able to influence people's perception on any issues. Zulkifli (2011) mentioned Blog is a modern media technology that is created and designed to meet the needs of the nature of new media and independent networks, which is known as the blogosphere. Islamic weblogs or Islamic blogs are part of religious weblogs. In general, the content of the Islamic weblogs is conveying Islamic religion, teachings, and practices. Islamic weblogs play a similar function with the Islamic websites, which act a platform to disseminate information on Islam, but differ in the aspect of contents' presentation. Various elements have been highlighted by various scholars in their attempt to define and describe the Islamic websites. According to Bunt (2003), the key in defining the Islamic websites is the content of the website especially in the aspect of authority and Islamic content. In addition, many researchers have described the concept of the Islamic websites and Islamic weblogs in the context of Islamic cultural perspectives. As stated by Rahim et al. (2008), Islamic websites served as a site which emphasises on the Islamic ideologist, rules and ethics. However, Mahmud et al. (2011) then explain the concept of Islamic websites and Islamic weblogs in a broader perspective. The authors discussed that the Islamic websites is being acknowledged as the websites that stress on the essential's lessons of Islam. Aliyu et al. (2010) propose the definition of Islamic websites in three different aspects that are including (i) sites that delivers the Islam fundamental like Solat, Muslim Creeds, Hajj, and others for the purpose of teaching and learning, (ii) sites that describe good values of Islam, according to Shari'ah, and (iii) sites which being developed for the purpose of describing the commandments of Allah in compliance with the Prophet Muhammad's (SAW) teachings

The vast review of literature in Information System Management on digital content described that there are few important factors that contributed to the continued uses of Information System applications like weblog. It was acknowledged that factors such as confirmation, perceived usefulness, credibility, objectivity, and reliability on information content has a vital role to encourage Islamic weblogs to carry on being used by the Internet user.

\section{Continuance Use}

It is important to emphasize continuance use in the Information System (IS) field. Continuance use is about the ongoing use of the website. Few prominent IS models such as Technology Acceptance Model (TAM) and Expectation Confirmation Theory (ECT) have been applied by researchers for understand about continuance intention to use an information system. The theory is used to embrace the positive and negative expectations about the information systems (Hoehle, Huff \& Goode, 2011). According to Bhattacherjee (2001), continuance use is the individual's intention to continue to use the blogs continually. Continuous users could gain more profit than to have new users. There are several factors in information studies to predict the continuance intention. It is about the ongoing use of the information system in the future as well the user will continue to use the website. In this study, the satisfaction will lead the people to continue or discontinue using the Islamic website. It is important to understand the factors influencing the continuance intention of Islamic websites. The utilization of Information System functions is important to influencing intention to continue the information system (Larsen, Sorebo \& Sorebo, 2009). 
Confirmation is one of the elements studied in the Expectation-Confirmation Theory (ECT). Initially, ECT consists of expectation, performance, confirmation, satisfaction and repurchase intention. It is used predict the customers' satisfaction, repurchase behaviour and marketing. ECT also explains that satisfaction is the most significant antecedent of repurchase behaviour and the users' satisfaction is being influenced by expectation and confirmation. Next, ECT also explains that confirmation is negatively being influenced by expectation, but positively being influenced by perceived performance. The expectation confirmation is commonly used to address the question of how consumers summarize their experiences which then influences their subjective evaluation of satisfaction (Oliver 1993). The confirmation of expectations proposes that users gained expected benefits through their usage experiences with the Information Technology (IT), which then created a positive effect on users' satisfaction. Confirmation also has an influence towards the continuance intentions in two indirect ways which are by influencing the users' satisfaction toward the service and by influencing users' perceptions on the usefulness aspect (Lee, 2010). Users with positive confirmation will have a greater satisfaction level, which indirectly attracts them to continue to use the products or services. Bhattacherjee (2001) mentioned that the confirmation of expectation is being referred to the users' insight of the similarity between expectation on the use of IS/IT and the actual performance. In other words, confirmation is the situation where the actual performance of the IS/IT is similar to the users' expectations. Venkatesh et al. (2011) then defined the positive or negative disconfirmation as the situations when things are better or worse than the expectations $\mathrm{A}$ study conducted by Hsu et al. (2008) among the blog users in Taiwan reveals a coherent effect of users' expectation either before or after the usages. The study discovers that confirmation has contributed a positive impact on satisfaction and perceived usefulness. Other past research also shows that the confirmation has immense influence on the satisfaction (Bhattacherjee \& Premkumar, 2004; Thong et al., 2006; He and Wei, 2009; Lin et al., 2012). Therefore, in the context of this study, when the actual use of the Islamic weblogs matches or exceeds the initial expectation of the users, confirmation will exist, and thus lead to user's satisfaction.

\section{Perceived Usefulness}

In the information System discipline, perceived usefulness is the one factor to the customer's intention to continue to use the information system and weblog is part of it. Perceived usefulness is the degree attained when people believe and are free of the compulsion factor to use a certain Information System applications (Davis 1989). Perceived usefulness is about the users expected benefits from using information systems. Perceived usefulness will act as an influential tool that will increase social influences of user intention towards continuance to use (Al-Maghrabi \& Dennis, 2011). Burke (1996) also has mentioned perceived usefulness is the primary prerequisite of the technology acceptance as well depends on the user expectations on how it is useful to them. The usefulness and accuracy of the website will influence customer attitudes. Users may continue without hesitation for using the services provided if they consider it useful (Bhattacherjee, 2001). Perceived usefulness predicts information technology use and intention to use (Gefen and Straub, 1997). Thus, perceived usefulness is important in aspects of Islamic website use in which the user evaluates the usefulness of the information system.

\section{Satisfaction}

There is much definition on user satisfaction and has been widely studied in the Information System and it is important for Information Success measures (Delone \& Mclean, 2003). Oliver (1981) firstly describes satisfaction as the customers' evaluation of the products or services after the purchase

$$
\text { https://doi.org/10.24035/ijit.19.2021.196 }
$$


compared to the customers' prior expectations. He also noted that satisfaction is the emotion surrounding a consumer's prior feelings about the consumer experience. Swan and Trawick (1981) stated that satisfaction determines intentions to utilize or not to utilize in the future. Satisfaction is about the user's affect with the blog use. He also indicates that; the satisfaction was a significant predictor of Information System continuance. A satisfied use will tend to continue to use the same website.

$$
\text { Credibility }
$$

Islamic teaching is concerned regarding credibility of information. It is firmly mentioned in Al-Quran which is Allah has stated clearly in Surah Al-Hujurat about Information credibility: "O believers! If a wicked person brings you a piece of news, inquire first into its truth, lest you should wrong others unwittingly and repent of what you have done." (Al-Hujurat: 6).

The credibility of the website has nowadays become more important. Credibility is about believability. In information context, credibility of information is about the believability of information (Fogg \& Tseng, 1999). There are two components of credibility which is trustworthiness and expertise. In Human Computer interaction research, there are the most common phrases used to identify the credibility, such as "trust the information", "accept the advice" and "believe the output". Since Islam promoting the way of life, Al-Quran reminds people think and careful about credibility any information they receive. By nature of Web blogs, it is a potential application tool for dakwah to provide solid understanding to the people. It is also highly effective in convincing people to share with each other about the Islamic information by multimedia approaches. With the capability of twoway communication, the religious interpretation and authority of web blogs can be questionable directly. Islamic web blog able to assist conventional Islamic teaching to provide authentic knowledge from the credible sources of information.

\section{Objectivity}

In line with transparent ideologies, an Islamic website should be clearly identified, have clear objectives or mission and be easy for the users to compare with their own needs. The main objective of the website should be clearly stated, which is to disseminate good Islamic practices. The content of the sites must avoid hidden agenda like misrepresentative statements without appropriate reliable references. This situation is associated with the content objectivity of the sites. It is no doubt that objectivity is also another feature that helps to attract people to use the websites. Many scholars in the area of Information System provide serious attention about the objectivity of information quality over the Internet. According to Alexander \& Tate (1999) and Ahmed \& Suleman (2007), the term objectivity is being explained as the degree to which the information or facts provided is free from any biases or personal feelings. Inline to this definition, Aliyu et al. (2012) and Suleman (2005) further explains that the information objectivity is where the information provided or shared should cover all the points of views of the particular topics and do not incline to the real meaning or principles. In the perspective of Islam, it is essential for the people to follow the Quran and Sunnah and avoid having different opinions and views. It is unavoidable situation having dissimilar perception, opinion, and views relating to Islam, but they must follow to the Quran and Sunnah to overcome the differences. Apart from that, Islam encourages peace and unity among people. From the perspective of this study, the information objectivity is best described as the feature where the information shared is free from biases towards or against the people as well as other religions. The Information System Scholars agreed that content of websites must have the objectivity feature for influence the internet users towards the use of the websites (Aliyu et al., 2010; Ahmed \& Suleman, 2007; Karim \& Hazmi, 2005). Hence, in the context of this study, objectivity is listed as one of the dimensions in content factors and expected to have an impact towards the users' satisfaction. This

$$
\text { https://doi.org/10.24035/ijit.19.2021.196 }
$$


study denotes that weblogs should not have misleading information, do not bias or against the Islamic ideologies and Islamic scholars' thoughts.

\section{Reliability}

Reliability is also another feature that enhances the use of the websites. In general, the reliability is being referred to the ability of a system or technology to carry out the services or functions as guaranteed dependably and precisely (Han, 2004). Koops (2004) mentioned that reliability in connection with well-defined as the possibility of accurate information The author further explained that reliability also depends on the value of information appreciated by the Internet users after gain experience when using information and recognizing the level risk of information. Besides, both Kim et al. (2009) and DeLone \& Mclean (2003) agree that the content reliability is associated with the website owner's ability, honesty as well as their readiness to share and manage the information. Parasuraman et al. (2002) has mentioned that the reliability of a website is an ability to keep service dependably and accurately. Therefore, based on the discussions, it can be concluded that reliability is associated to trust. Reliability may have an equal meaning of credibility, quality, trustworthiness, and accuracy, but the differences among them are blurred (Adams, 2010). In Islamic teaching content itself and authorship will determine the reliability of information (Rasheed et al., 2013). Apart of it, much effort has been done by Muslim scholars in defining the appropriate methods and approaches for measuring Islamic contents. There are two dimensions of reliability are being introduced, where one is associated to the content and the other one is on the authorship and narration chain (Ishak et al., 2011; Karim \& Hazmi, 2005). There are studies showed that Muslim users are concerned about the unreliable content and it leads to have some doubt to certain Islamic websites or blogs (Karim \& Hazmi, 2005; Ibrahim et al., 2009; Al-Shamaileh, 2011). Hence, aspects of religion and ethics are important for them when they use the websites. They felt conveniences when those websites demonstrated their Islamic culture and ethics. In Islamic perspective, websites' content and interface are supposed to reflect the reliability of the information provided (Ishak et al. 2011). Ibrahim et al. (2010) argue that until now, website's reliability from the Islamic perspective has not been studied in a systematic way. Therefore, it is necessary for Islamic scholars to identify the dimensions that could increase the reliability of Islamic websites to gain trust from the Muslims.

Analysis of literature has led to the established a research framework to guide how the research will take place. Since the research is done with the objective to find what are the factor All factors discussed have been taken as variable for the research framework stated in Figure 1.

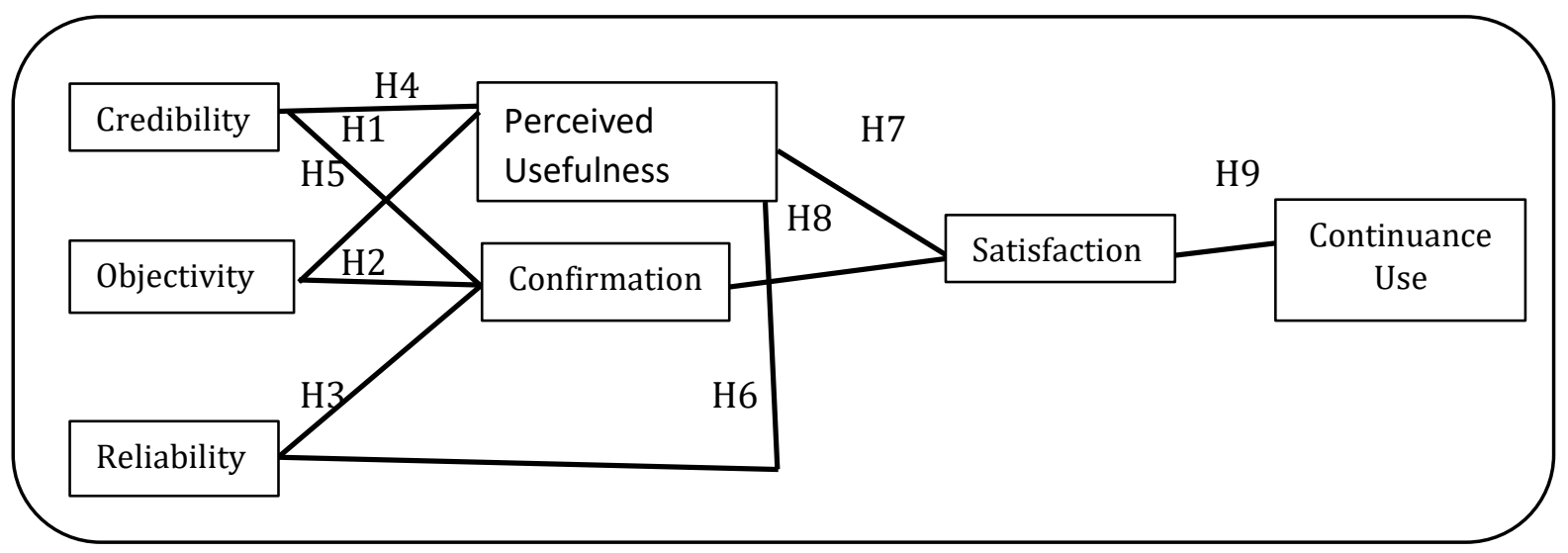

Figure 1: Research Framework

https://doi.org/10.24035/ijit.19.2021.196 
Justification derived from discussion review of the literature, researcher posits that there is a relationship between variables discovered and need to be tested by development of hypothesis.

H1: Credibility (CR) significantly predicts Confirmation (CF).

H2: Objectivity (OB) significantly predicts Confirmation (CF).

H3: Reliability (RE) significantly predicts Confirmation (CF).

H4: Credibility (CR) significantly predicts Perceived Usefulness (US).

H5: Objectivity (OB) significantly predicts Perceived Usefulness (US).

H6: Reliability (RE) significantly predicts Perceived Usefulness (US).

H7: Perceived Usefulness (US) significantly predicts Satisfaction (ST).

H8: Confirmation (CF) significantly predicts Satisfaction (ST).

H9: Continuance Use (CO) significantly predicts Satisfaction (ST).

\section{Methodology}

This study is being conducted to identify the relationships that occur between the content factors users' satisfaction, and the continuance used of Islamic weblogs. Hence, to achieve the objectives of the study, the quantitative approach is being selected as the method of this research. Quantitative research is based upon the quantitative measurements of some characteristics and applicable to be applied in the situation or setting that can be expressed through numerical data or quantities. Taken from Aliaga \& Gunderson (2002), the quantitative approach is being described as an approach adopted by the researchers to explain certain phenomena by gathering numerical data that are being analysed using mathematically based methods. In this study, all the variables proposed in the framework are being measured using the five-point Likert scale. The questionnaire was distributed to 800 Islamic religious subject teachers in Kuala Lumpur Federal Territory However, out of 800, only 550 questionnaires are successfully returned. Eventually, three questionnaires are removed. Hence, only 497 questionnaires are found usable for further analyses. Analysis of the research data was conducted by using SPPS statistical package SEM.

\section{Finding}

Based on the research data collected by questionnaire distribution, the researcher has sought the research finding. Descriptive analysis for conformation factors and hypothesis testing to examine the relationship of each factor was performed by the researcher.

\section{Continuance Use}

Table 4.0 demonstrates the finding of descriptive analysis for factors of digital Islamic information content that encourage the people to continue using the Islamic weblogs. By value means is 5.0, analysis showed that mean for Continuance Use is about 4.06, suggesting that the respondents of the study have intentions to continue use the Islamic weblogs in searching and disseminating the Islamic information. The overall analysis of standard deviation is about 0.668 , which is less than 1 , implying that; substantially the respondents have almost similar opinion about the continuance use of the Islamic weblogs. Further examination on the results revail that the highest mean (4.10) is for "I will continue using Islamic web blogs in the future", while the lowest (4.03) is for "I will introduce Islamic web blogs to friends and relatives". 
Table 4.0 - Descriptive Statistics for Continuance Use of Islamic Weblogs

\begin{tabular}{|l|l|c|c|}
\hline & \multicolumn{1}{|c|}{} & Mean & Std. Dev \\
\hline C01 & $\begin{array}{l}\text { I want to continue using Islamic Web } \\
\text { Blogs }\end{array}$ & 4.04 & .654 \\
\hline C02 & $\begin{array}{l}\text { I will introduce Islamic web blogs to } \\
\text { friends and relatives }\end{array}$ & 4.03 & .676 \\
\hline C03 & $\begin{array}{l}\text { My intention is to continue using } \\
\text { Islamic web blogs }\end{array}$ & 4.07 & .656 \\
\hline C04 & $\begin{array}{l}\text { I will continue using Islamic web blogs } \\
\text { in the future }\end{array}$ & 4.10 & .685 \\
\hline \multicolumn{2}{|l}{} \\
\hline
\end{tabular}

\section{Satisfaction}

Finding for Satisfaction (ST) variable was described by descriptive analysis in Table 4.1. By value mean analysis about 3.91, the respondents substantially were satisfied with the use of Islamic weblogs in searching and disseminating the Islamic information. By value standard deviation analysis is about 0.681 , which is less than 1.0, implying that; majority of the respondents have almost identical opinion about the satisfaction of using the Islamic weblogs. Further analysis of the results suggests that the highest mean (3.95) is for "Overall I'm fully satisfied using the Islamic web blogs", while the lowest (3.80) is for "The experience of using the web blogs has never been frustrating".

Table 4.1 - Descriptive Statistics for Satisfaction of Using Islamic Weblogs

\begin{tabular}{|c|c|c|c|}
\hline & & Mean & Std. Dev \\
\hline ST2 & $\begin{array}{l}\text { The experience of using the web blogs has } \\
\text { never been frustrating }\end{array}$ & 3.80 & .684 \\
\hline ST3 & I enjoy using the Islamic Web Blogs & 3.99 & .669 \\
\hline ST4 & $\begin{array}{l}\text { Using the Islamic blogs bring a sense of } \\
\text { satisfaction to me }\end{array}$ & 3.90 & .678 \\
\hline \multirow[t]{2}{*}{ ST5 } & $\begin{array}{l}\text { Overall, I'm fully satisfied using the Islamic web } \\
\text { blogs }\end{array}$ & 3.95 & .653 \\
\hline & & 3.91 & 0.671 \\
\hline
\end{tabular}

\section{Perceived Usefulness}

Finding on Perceived Usefulness (US) variables was analysed descriptively as Table 4.2. The finding discovers overall mean for Perceived Usefulness is about 4.04. It is demonstrating that the respondents largely believe that the use of Islamic weblogs increase or improve their performance in searching and disseminating the Islamic information. Standard deviation analysis of the finding is about 0.662 , which is less than 1.0, implying that; the respondents largely have almost similar opinion about the perceived usefulness of using the Islamic weblogs. Further examination on the finding discovers that the highest mean (4.08) is for "The Web Blogs help to improve my knowledge and skill", while the lowest (4.00) is for "The Web Blogs are useful for exchanging and sharing information". 
Table 4.2 -Descriptive Statistics for Perceived Usefulness of Islamic Weblogs

\begin{tabular}{|c|c|c|c|}
\hline & & Mean & Std. Dev \\
\hline US1 & The Web Blogs help me in the learning process & 4.02 & .663 \\
\hline US2 & $\begin{array}{l}\text { The Web Blogs help to improve my knowledge } \\
\text { and skill }\end{array}$ & 4.08 & .630 \\
\hline US3 & $\begin{array}{l}\text { The Web Blogs are useful for exchanging and } \\
\text { sharing information }\end{array}$ & 4.00 & .679 \\
\hline \multirow[t]{2}{*}{ US4 } & $\begin{array}{l}\text { The Web Blogs are useful for my personal } \\
\text { development }\end{array}$ & 4.07 & .675 \\
\hline & & 4.04 & 0.662 \\
\hline
\end{tabular}

\section{Confirmation}

Finding on for Confirmation (CF) variables was analysed descriptively as Table 4.3. By value mean analysis for Confirmation is about 3.87, it is suggesting that the respondents of the study substantially agreed that the performance of the Islamic weblogs in searching and disseminating the Islamic information is closely to their expectation. Standard deviation analysis of the finding is about 0.673 , which is less than 1.0, implying that; majority of the respondents overall have almost the same opinion about the confirmation of using the Islamic weblogs. Further examination on the finding discovers that the highest mean (3.90) is for "My decision to use the Islamic Web blogs was a wise one", while the lowest (3.85) is for "The Information provided by web blogs fulfil my expectation".

Table 4.3 - Descriptive Statistics for Confirmation of Using Islamic Weblogs

\begin{tabular}{|c|c|c|c|}
\hline & & Mean & Std. Dev \\
\hline CF1 & $\begin{array}{l}\text { The information provided by Islamic Web Blogs } \\
\text { fulfils my need }\end{array}$ & 3.87 & .671 \\
\hline CF2 & $\begin{array}{l}\text { The Information provided by web blogs fulfil } \\
\text { my expectation }\end{array}$ & 3.85 & .658 \\
\hline CF3 & $\begin{array}{l}\text { My decision to use the Islamic Web blogs was a } \\
\text { wise one }\end{array}$ & 3.90 & .688 \\
\hline \multirow[t]{2}{*}{ CF4 } & The Web Blogs fulfil my requirement & 3.86 & .673 \\
\hline & & 3.87 & 0.673 \\
\hline
\end{tabular}

Credibility

Finding on for Credibility (CR) variables as Content factor was analysed descriptively as Table 4.4. By value mean analysis for Credibility about 3.92, it is suggesting that the respondents of the study agree on the credibility of the Islamic weblogs in disseminating the Islamic information. Standard deviation analysis of the finding is about 0.748 , which is less than 1 , implying that; majority of the respondents overall have almost equal opinion about the credibility of the Islamic weblogs as a source of information. Further examine on the results suggests that the highest mean (3.98) is for "The Web Blogs are hosted by a Muslim" and "The Web Blogs use renowned Islamic scholar's opinion", while the lowest (3.83) is for "The Web Blogs provide owner credential". 
Table 4.4 - Descriptive Statistics for Credibility of Islamic Weblogs

\begin{tabular}{|l|l|c|c|}
\hline & & Mean & Std. Dev \\
\hline CR1 & The Web Blogs are owned by Muslim & 3.95 & .762 \\
\hline CR2 & The Web Blogs are hosted by a Muslim & 3.98 & .721 \\
\hline CR3 & The Web Blogs have clearly defined objectives & 3.96 & .735 \\
\hline CR4 & The Web Blogs provide owner credential & 3.83 & .779 \\
\hline CR5 & The Web Blogs provide author's credential & 3.84 & .754 \\
\hline CR6 & $\begin{array}{l}\text { The Web Blogs use renowned Islamic books for } \\
\text { reference }\end{array}$ & 3.92 & .750 \\
\hline CR7 & $\begin{array}{l}\text { The Web Blogs use renowned Islamic scholar's } \\
\text { opinion }\end{array}$ & 3.98 & .736 \\
\hline & \multicolumn{2}{|l}{} & $\mathbf{0 . 7 4 8}$ \\
\hline
\end{tabular}

Objectivity

Table 4.5 demonstrated the results of descriptive analysis for Objectivity (OB) variables, which demonstrate the Content Factor. The overall mean for Objectivity is 3.76, suggesting that the respondents of the study agree the information provided in the Islamic weblogs is free from any biases or personal feelings. The respondents largely have almost identical opinions about the objectivity of the Islamic weblogs in sharing and disseminating the information. It proved by standard deviation analysis is 0.757 , which is less than 1.0. Further examination on the results reveals that the highest mean (3.88) is for "The Web Blogs contain no discrimination against all the sahabah", while the lowest (3.67) is for "The Web Blogs contain no innovative (Bid'ah) information".

Table 4.5 - Descriptive Statistics for Objectivity of Islamic Weblogs

\begin{tabular}{|l|l|c|c|}
\hline & \multicolumn{1}{|c|}{ Mean } & Std. Dev \\
\hline OB1 & $\begin{array}{l}\text { The Web Blogs contain no misleading } \\
\text { information }\end{array}$ & 3.69 & .775 \\
\hline OB2 & $\begin{array}{l}\text { The Web Blogs contain no innovative (Bid'ah) } \\
\text { information }\end{array}$ & 3.67 & .778 \\
\hline OB3 & $\begin{array}{l}\text { The Web Blogs contain no bias interpretation of } \\
\text { the Quran }\end{array}$ & 3.79 & .731 \\
\hline OB4 & $\begin{array}{l}\text { The Web Blogs contain no bias interpretation of } \\
\text { hadith }\end{array}$ & 3.75 & .756 \\
\hline OB5 & $\begin{array}{l}\text { The Web Blogs contain no discrimination } \\
\text { against all the sahabah }\end{array}$ & 3.88 & .722 \\
\hline OB6 & $\begin{array}{l}\text { The Web Blogs contain no racial /ethnic biased } \\
\text { /stereotyped information }\end{array}$ & 3.80 & .743 \\
\hline OB7 & $\begin{array}{l}\text { The Web Blogs contain information that } \\
\text { are not against the opinion of Islamic } \\
\text { scholars' }\end{array}$ & 3.75 & .772 \\
\hline OB8 & $\begin{array}{l}\text { The Web Blogs contain information that are not } \\
\text { against other Islamic ideologies }\end{array}$ & 3.73 & .752 \\
\hline OB9 & $\begin{array}{l}\text { The Web Blogs contain information that are not } \\
\text { against other schools of thought (Mazhab) }\end{array}$ & 3.76 & $\mathbf{0 . 7 5 7}$ \\
\hline & \begin{tabular}{l}
$\mathbf{3 . 7 6}$ \\
\hline
\end{tabular} \\
\hline
\end{tabular}

https://doi.org/10.24035/ijit.19.2021.196 


\section{Reliability}

Finding on Reliability (RE) variables as Content factor was analysed descriptively as Table 4.6. By value mean analysis of the study for Reliability about 3.77, it is suggesting that the respondents substantially agree on the reliability of the Islamic weblogs in disseminating the Islamic information. Standard deviation analysis of the finding is about 0.732 , which is less than 1 , implying that; majority of the respondents overall have almost equal opinion about the Reliability of the Islamic weblogs as a source of information. Further examination on the results suggests that the highest mean (3.86) is for "The Web Blogs contain up to date information", while the lowest (3.71) is for "The Web Blogs contain complete reference".

Table 4.6 - Descriptive Statistics for Reliability of Islamic Weblogs

\begin{tabular}{|c|c|c|c|}
\hline & & Mean & Std. Dev \\
\hline RE1 & The Web Blogs contain complete reference & 3.71 & .751 \\
\hline RE2 & The Web Blogs contain up to date information & 3.86 & .710 \\
\hline RE3 & $\begin{array}{l}\begin{array}{l}\text { The Web Blogs contain } \\
\text { information }\end{array} \\
\end{array}$ & 3.76 & .716 \\
\hline RE4 & The Web Blogs contain accurate information & 3.79 & .741 \\
\hline RE5 & The Web Blogs contain consistent information & 3.74 & .716 \\
\hline RE6 & $\begin{array}{l}\text { The Web Blogs contain the date of document } \\
\text { creation }\end{array}$ & 3.76 & .759 \\
\hline \multirow[t]{2}{*}{ RE7 } & The Web Blogs contain links to original sources & 3.75 & .730 \\
\hline & & 3.77 & 0.732 \\
\hline
\end{tabular}

The table 4.7 below presents the findings of hypothesis tests. SEM is being conducted to test the hypotheses constructed through the path coefficient and the critical ratio (C.R.) as illustrated in the table below.

Table 4.7 - Hypothesis Analysis

\begin{tabular}{|c|c|c|c|c|c|c|c|c|}
\hline $\begin{array}{l}\text { Hypothe } \\
\text { sis }\end{array}$ & \multicolumn{3}{|c|}{ Correlation } & Estimate & S.E. & C.R. & P-value & Result \\
\hline$H 1$ & CR & ? & $\mathrm{CF}$ & 0.057 & 0.044 & 1.293 & 0.196 & Not Supported \\
\hline$H 2$ & $\mathrm{OB}$ & 回 & $\mathrm{CF}$ & -0.005 & 0.060 & 0.086 & 0.932 & Not Supported \\
\hline$H 3$ & $\mathrm{RE}$ & 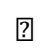 & $\mathrm{CF}$ & 0.120 & 0.059 & 2.034 & 0.042 & Supported \\
\hline$H 4$ & CR & ? & US & -0.025 & 0.043 & 0.578 & 0.563 & Not Supported \\
\hline H5 & $\mathrm{OB}$ & 包 & US & 0.075 & 0.059 & 1.271 & 0.204 & Not Supported \\
\hline H6 & $\mathrm{RE}$ & ? & US & -0.035 & 0.058 & 0.610 & 0.542 & Not Supported \\
\hline$H 7$ & US & ? & ST & 0.370 & 0.056 & 6.567 & $* * *$ & Supported \\
\hline H8 & $\mathrm{CF}$ & 回 & ST & 0.519 & 0.054 & 9.647 & $* * *$ & Supported \\
\hline H9 & $\mathrm{CO}$ & ? & ST & 0.470 & 0.087 & 5.375 & $* * *$ & Supported \\
\hline
\end{tabular}

$H 1$ suggests that there is a relationship between Credibility and Confirmation. However, the SEM's results show that $\mathrm{p}$-value is $0.196(\beta=0.057$, S.E. $=0.044$, C.R. $=1.293)$, which is above the significant values ( 0.1 or 0.001$)$. Hence, the results of this study suggest that there is no relationship between the Credibility of the weblogs and the Confirmation factors. In other words, the hypothesis (H1) is not supported. 
$H 2$ suggests that the Objectivity of the Islamic weblogs significantly predicts the Confirmation factor. The study reports that the p-value is $0.932(\beta=-0.005$, S.E. $=0.060$, C.R. $=-0.086)$, which is higher than the significant values $(0.1$ or 0.001$)$. Therefore, the finding of this study suggests at the objectivity does not significantly predict the Confirmation factor, which indicates that there is no relationship between the Objectivity of the weblogs and the Confirmation factors. In other words, the hypothesis $(H 2)$ is not supported.

Next, $H 3$ suggests that there is a relationship between Reliability and Confirmation. The SEM's results show that $p$-value is $0.042(\beta=0.120$, S.E. $=0.059$, C.R. $=2.034)$, which is between the recommended significant values $(0.1$ or 0.001$)$. Hence, the finding of the present study denotes that Reliability of the Islamic weblogs significantly predict the Confirmation factors. In other words, the hypothesis $(H 3)$ is supported.

H4 suggests that the Credibility of the Islamic weblogs significantly predicts the Perceived Usefulness factor. The study reports that the p-value is $0.569(\beta=-0.024$, S.E. $=0.043$, C.R. $=-0.570)$, which is higher than the significant values (0.1 or 0.001). Thus, the finding of this study encounter that the credibility does not significantly predict the Perceived Usefulness factor, which indicates that there is no relationship between the Credibility of the weblogs and the Perceived Usefulness factors. In other words, the hypothesis (H4) is rejected.

$H 5$ suggests that there is a relationship between Objectivity and Perceived Usefulness. The SEM's result reported that the p-value is $0.205(\beta=0.074$, S.E. $=0.059$, C.R. $=1.268)$, which is above the significant values $(0.1$ or 0.001$)$. Hence, the finding of this study discovers that there is no relationship between the Objectivity of the weblogs and the Perceived Usefulness factor. In other words, the hypothesis (H5) is not supported.

Apart from that, $H 6$ suggests that the Reliability of the Islamic weblogs significantly predicts the Perceived Usefulness factor. The study reports that the $p$-value is $0.542(\beta=-0.035$, S.E. $=0.058$, C.R. $=-0.609$ ), which is higher than the significant values ( 0.1 or 0.001$)$. Thus, the finding of this study suggests that the reliability does not significantly predict the Perceived Usefulness factor, which indicates that there is no relationship between the Reliability of the weblogs and the Perceived Usefulness factors. In other words, the hypothesis $(H 16)$ is rejected.

The study also concerns the relationships between the Perceived Usefulness and the Satisfaction of the Islamic weblogs. H7 suggests that there is a relationship between Perceived Usefulness and the Satisfaction. The SEM's results indicate that the p-value is less than $0.001(\beta=$ 0.370 , S.E. $=0.056$, C.R. $=6.567)$. The p-value reported meets the significant values $(0.1$ or 0.001$)$. Hence, the finding of this study suggests that Perceived Usefulness of the weblogs significantly predict the Satisfaction factors. In other words, the hypothesis (H7) is supported.

H8 suggests that the Confirmation factor significantly predicts the Satisfaction of the Islamic weblogs. The SEM's results of the present study reports that the $p$-value is less than $0.001(\beta=0.519$, S.E. $=0.054, C . R .=9.647)$, which meets the required significant values $(0.1$ or 0.001$)$. Thus, the finding of this study suggests that the Confirmation factor significantly predicts the Satisfaction of the Islamic weblogs, which indicates that there is a relationship between the Confirmation and the Satisfaction factors. In other words, the hypothesis (H8) is accepted.

H9 suggests that the Satisfaction factor significantly predicts the Continuance Use of the Islamic weblogs. The SEM's results of the present study reports that the $p$-value is less than 0.001 ( $\beta$ $=0.470$, S.E. $=0.087$, C.R. $=5.375)$, which meets the required significant values (0.1 or 0.001). Thus, the finding of this study suggests that the Satisfaction on the Islamic weblogs significantly predict the Continuance Use of the Islamic weblogs, which indicates that there is a relationship between the Satisfaction and the Continuance Use factors. In other words, the hypothesis (H9) is supported. 


\section{Discussion}

The purpose of the study is to investigate the promoting factors for information sharing through the weblogs focusing on the Islamic weblogs. In detail, the study measured the level of user's rating of the Content Factors.

Hence, for the purpose of this study, the content factor is being measured by three different aspects namely credibility, objectivity and reliability of the contents shared over the Islamic weblogs. The table 5.1 below clearly shows the results of the content factors analysis.

Table 5.1 - Content Factors

\begin{tabular}{|l|c|c|c|}
\hline \multirow{4}{*}{$\begin{array}{l}\text { Content } \\
\text { Factors }\end{array}$} & Constructs & Overall Mean & $\begin{array}{c}\text { Overall Standard } \\
\text { Deviation }\end{array}$ \\
\cline { 2 - 4 } & Credibility & 3.92 & 0.748 \\
\cline { 2 - 4 } & Objectivity & 3.76 & 0.757 \\
\cline { 2 - 4 } & Reliability & 3.77 & 0.732 \\
\hline
\end{tabular}

Credibility of information is often associated with trustworthiness, integrity, and believability of something. It is crucial to examine the perceived credibility of a weblog since the Islamic weblogs are now becoming a significant source of information among Muslim users. The overall mean for Credibility is 3.92 in regards that the respondents of the study agree that the credibility of the Islamic weblogs is important. Generally, the content credibility is being described as the degree to which the user evaluates the content provided as complete, accurate, unbiased, appropriate, and accurately understood. Apart from that, in delivering the Islamic information to others, the bloggers must also be concerned about the credibility of the information by using renowned Islamic scholar's opinion to support the content. A source with some authority, especially from those who are an expert in the subject area are seen as more credible.

The second construct of the Content Factors is the content objectivity. Content objectivity is being referred to the extent to which the information shared over the weblogs are real information and it does not come from perception and free of biases (Alexander and Tate, 1999). The findings have illustrated that the overall mean for content objectivity is 3.76, which indicates that most of the respondents come to an agreement that an Islamic weblog should always be free from any biases or personal feelings. As discussed in the earlier chapter, the previous researchers proposed that content objectivity is one of the features that have an influence towards the use of the weblogs. Besides, the Islamic weblogs should be clearly identified, have a clear objective and be easy for the users to compare with their own needs. In the context of Islam, the content of the Islamic weblogs should always follow the Quran and Sunnah and avoid having different opinions and views.

In terms of reliability, within the context of online information, the content reliability aspect is often associated with the updated, accurate, consistent, comprehensive, and satisfactory information. Reliability of content relates to the website owners' ability, sincerity, and willingness to provide and manage information (Aliyu et al. 2013). The findings discussed reveal that the overall mean for content reliability is 3.77, indicating that the respondents of the study agree the reliability of the Islamic weblogs in disseminating the Islamic information is one the essential aspects in content evaluation. Users believe that in order for a weblog to be considered as reliable, the information shared needs be up to date and accurate. Apart from that, studies by Kim et al. (2009) and DeLone \& McLean (2003) mention that reliability of content is described as the extent to which the ability, sincerity and willingness of the site's owners to provide and manage information. This present study reveals that the users categorized the weblogs as a reliable source of information when the information shared are up to date, complete, accurate, comprehensive, and consistent.

The findings show that four out of nine hypotheses constructed are supported. The results indicate that the Reliability is a Content Factor that has a strong relationship that influences the

$$
\text { https://doi.org/10.24035/ijit.19.2021.196 }
$$


continuance used of the Islamic weblogs. However, to become a strong content factor for continuance use, the hypothesis testing as well indicated that Reliability has to be supported by other factors such as confirmation and Satisfaction as Figure 2.0.

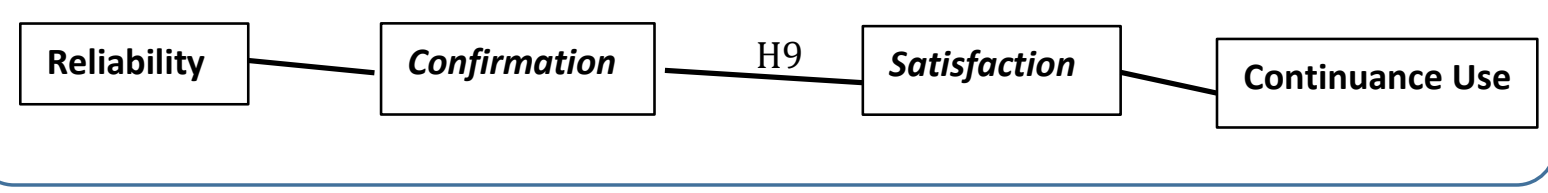

\section{Figure 2.0 Weblog Content Factor}

To conclude, this study has sought to unravel the potential content elements that influence people to continue using the weblogs as the tools to search and share the religious information, instead of the well-known satisfaction factor. Undoubtedly, the weblogs are not only a platform for people to share information. In today's environment, the weblogs have been recognized as a platform to promote the services, for businesses as well as for social interaction. Islamic weblogs are no exception to maximize for Dakwah. Despite sharing information, Islamic weblogs also offer Islamic services to the users. In addition, Islamic weblogs allow for interaction and communication among the Muslim communities from diverse area. With concerns to the content factors, it comes to light that, for the people who always seek for reliable and accurate information, the content itself possesses great value for them. This means that, in an effort to encourage people to revisit the Islamic weblogs, the blog owners have to think of a proper way to deliver the Islamic information over the weblogs to ensure that the information provided are credible, accurate, complete and reliable for the readers. People seem to be looking for information that is useful for them who fulfil their needs and helps to facilitate their life to overcome confusion. Therefore, bloggers must have a guideline to ensure that the information shared over the weblogs meet the required criteria.

\section{References}

Adams, S. A. (2010). Revisiting the online health information reliability debate in the wake of "web 2.0": an inter-disciplinary literature and website review. International journal of medical informatics, $79(6), 391-400$.

Ahmed, M., \& Suleman, I. (2007). Quality ranking of selected Islamic websites and their evaluation criteria. Journal of Islamic in Asia, 4(1).

Alexander, E. J., \& Tate, A. M. (1999). Web wisdom: How to evaluate and create information quality on the web. New Jersey: Lawrence Erlbaum Associates, Inc.

Aliaga, M. \& Gunderson, B. (2002). Interactive Statistics. Pearson Education: Virginia, America.

Aliyu, M., Mahmud, M., \& Tap, A. O. M. (2010, December). Preliminary investigation of Islamic websites design \& content feature: A heuristic evaluation from user perspective. In User Science and Engineering (i-USEr), 2010 International Conference on (pp. 262-267). IEEE.

Aliyu, M., Mahmud, M., Tap, M., \& Osman, A. (2012). Exploring Islamic website features that influence user satisfaction: a conceptual model. Procedia Social and Behavioural Sciences, 65(3), 656-661.

Aliyu, M., Mahmud, M., Tap, A. O. M., \& Nassr, R. M. (2013). An empirical investigation of factors influencing Islamic websites use and their positive impact from Muslim user perception. AsiaPacific Journal of Information Technology and Multimedia, 2(2), 13-26.

Al-Maghrabi \& Dennis, (2011), What Drives Consumers 'continuance Intention to E-Shopping? Conceptual framework and managerial implications in the case of Saudi Arabia, International Journal of Retail and Distribution Management, Vol. 39 No. 12, 2011pp. 899-926

$$
\text { https://doi.org/10.24035/ijit.19.2021.196 }
$$


Al-shamaileh, O., Sutcliffe, A., \& De Angeli, A. (2011). The effect of religious identity on user judgment of website quality. In Human-Computer Interaction-INTERACT 2011 (pp. 620-623). Springer Berlin Heidelberg.

Bhattacherjee, A. (2001). Understanding Information Systems Continuance: An ExpectationConfirmation Model. Management Information Systems Quarterly, 25(3), 351-370.

Bhattacherjee, A., \& Premkumar, G. (2004). Understanding Changes in Belief and Attitude Toward Information Technology Usage: A Theoretical Model and Longitudinal Test. Management Information Systems Quarterly, 28(2), 229-254.

Bunt, G. 2003. Islam in the Digital Age: E-Jihad, Online Fatwas and Cyber Islamic Environment. London:Pluto Press.

Burke, R.R. (1996), "Do you see what I see? The future of virtual shopping”, Journal of the Academy of Science, Vol. 25 No. 4, pp. 352-60.

Davis, F. D. (1989). Perceived usefulness, perceived ease of use, and user acceptance of information technology. MIS quarterly, 319-340.

Delone, W. H., \& McLean, E. R. (2003). The DeLone and McLean model of information systems success: a ten-year update. Journal of management information systems, 19(4), 9-30.

Fogg, B. J., \& Tseng, H. (1999, May). The elements of computer credibility. In Proceedings of the SIGCHI conference on Human Factors in Computing Systems (pp. 80-87). ACM.

Fogg, B. J., Lee, E., \& Marshall, J. (2002). Interactive Technology and persuasion. In J. P. Dillard \& M.

Pfau (Eds) London: Persuasion handbook: Developments in theory and practice (pp. 765-797).

London: Sage.

Gefen, D., \& Straub, D. W. (2003). Managing user trust in B2C e-services. E-service Journal, 2(2), 724.

Han, S., \& Baek, S. (2004). Antecedents and consequences of service quality in online banking: An application of the SERVQUAL instrument. Advances in Consumer Research, 31(2), 208-221.

He, W., \& Wei, K. K. (2009). What drives continued knowledge sharing? An investigation of knowledge-contribution and-seeking beliefs. Decision Support Systems, 46(4), 826-838.

Hoehle., H, Huff. S, and Goode., S. (2011), The Role of Continuous Trust in Information Systems Continuance, Journal of Computer Information Systems 52(4), June 2012.

Hsu, L. L., Ho, C. T., \& Huang, W. K. (2008). An empirical study of continuing usage in blog context: Based on expectation confirmation theory. Journal of Information Management, 15(4), 1-26.

Ibrahim, E. N. M., Noor, M. L. Md. \& Mehad, S. (2009). Trust or distrust in the web-mediated information environment (W-MIE) a perspective of online Muslim users. Journal of Enterprise Information Management, 22(5), 523-547.

Ishak, M. S., Omar, S. Z., Bolong, J., Abu Hassan, M., \& Abd Ghani, Z. (2011). Internet's Islamic Information Credibility Scale (IICS). Ulum Islamiyyah Journal (UIJ), 6(1), 3-28.

Karim, N. S. A., \& Hazmi, N. R. (2005). Assessing Islamic information quality on the Internet: A case of information about hadith. Malaysian Journal of Library and Information Science, 10(2), 51-66.

Kim, S. S., \& Son, J. Y. (2009). Out of dedication or constraint? a dual model of post-adoption phenomena and its empirical test in the context of online services. MIS Quarterly, 33(1), 49-70.

Knight and Burn (2005) Developing a Framework for Assessing Information Quality on the World Wide Web, Informing Science Journal Volume 8, P. 159-172

Koops, M. A. (2004). Reliability and the value of information. Animal Behaviour, 67(1), 103-111.

Larsen, Sorebo and Sorebo,(2009), The Role Of Task-Technology fit As Users' Motivation To Continue Information System Use, Computers in Human Behaviour 25 (2009) 778-784

Lee, M. C. (2010). Explaining and predicting users' continuance intention toward e-learning: An extension of the expectation-confirmation model. Computers \& Education, 54(2), 506- 
Mahmud, M., Aliyu, M. and Tap, A.O.M. (2010), Quality Rating of Islamic Websites Features: A SingleUser Evaluation, Published in: Proceeding of the 3rd International Conference on Information and Communication Technology for the Moslem World (ICT4M) 2010, Publisher: IIIE

Mahmud, M., Aliyu, M., Hussein, I. and Tap, A.O.M. (2011) Proposing a Working Definition and Framework to Evaluate Islamic Website. Proceeding of the 10 $10^{\text {th }}$ International Workshop on Internalization of Products and Systems (IWIPS 2011). Kuching Sarawak: Product \& Systems Internationalization, Inc, 91-103

Oliver, Richard (1981), "Measurement and Evaluation of Satisfaction Process in Retail Settings," Journal of Retailing, 57, pp 25-48

Parasuraman, A., Zeithaml, V., \& Berry, L. (2002). SERVQUAL: a multiple-item scale for measuring consumer perceptions of service quality. Retailing: critical concepts, 64(1), 140.

Rasheed Nassr, Murni Mahmud, Abu Osman Md Tap, Mansur Aliyu (2013), Measurable reliability dimensions for Islamic websites, 2013 International Conference on Research and Innovation in Information Systems (ICRIIS), IIIE

Rahim, W. A., \& WMI, N. L. (2008). M.: Inducting the Dimensions of Islamic Culture: A Theoretical Building Approach and Website IA Design Application. In 21st International Symposium Human Factors in Telecommunication: User Experience of ICTs (pp. 89-96). Prentice Hall.

Suleman, H. I. (2005). Developing web metrics for measuring the quality of Islamic websites. Unpublished Master Thesis presented to the Kulliyyah of Information \& Communication Technology, International Islamic University Malaysia. Kuala Lumpur. Malaysia.

Swan, J. E., \& Trawick, I. F. (1981). Disconfirmation of expectations and satisfaction with a retail service. Journal of Retailing, 57, 49-67

Thong, J. Y., Hong, S. J., \& Tam, K. Y. (2006). The effects of post-adoption beliefs on the expectationconfirmation model for information technology continuance. International Journal of HumanComputer Studies, 64(9), 799-810.

Van House, N. (2004, October). Weblogs: Credibility and collaboration in an online world. In Computer Supported Cooperative Work Workshop.

Venkatesh, V., Thong, J. Y., Chan, F. K., Hu, P. J. H., \& Brown, S. A. (2011). Extending the two-stage information systems continuance model: incorporating UTAUT predictors and the role of context. Information Systems Journal, 21(6), 527-555.

Zulkifli, M. A. A. M. (2011). Ironi komitmen terhadap ICT: ancaman blog di Malaysia. Jurnal Komunikasi; Malaysian Journal of Communication, 27(1), 53-72. 